\title{
急性期脳卒中リハビリテーション患者の 自宅退院の関連因子
}

一FIMを用いた関連要因分析一

Factors Influencing Outcomes in Rehabilitation of Stroke Patients

\author{
澤田 優子1）鈴木 雄介 $^{2)}$ 丸尾 優子2) 岡島 聡2) 福田 寛二2) \\ Yuko SAWADA ${ }^{1)}$, YUSUKE SUZUKI ${ }^{2)}$, YUKo MARUO ${ }^{2)}$, SATOSHI OKAJIMA ${ }^{2)}$, KANJI FUKUDA ${ }^{2)}$ \\ 1) Graduate School of Comprehensive Human Sciences University of Tsukuba: 1-1-1 Tennodai, Tsukuba 305-8575, Japan. \\ TEL/FAX +8129-853-3436e-mail ysawa1110@yahoo.co.jp \\ 2) Department of Rehabilitation, Kinki University School of Medicine
}

Rigakuryoho Kagaku 25(6): 965-968, 2010. Submitted Jul. 1, 2010. Accepted Aug. 23, 2010.

ABSTRACT: [Purpose] The aim of this study was to identify the factors related to discharge outcomes of acute stage rehabilitation stroke patients. [Subjects] The subjects were 135 stroke patients, admitted to and discharged from hospital for stroke treatment, who had performed acute stage rehabilitation. [Method] We performed related factor analysis using discharge outcome (discharged to home, transferred to another hospital) as the object variable, and age, gender, days before start of rehabilitation, days of hospital stay, presence of impaired consciousness, presence of motor paralysis, and the functional independence measure (FIM) at the start of rehabilitation as the explanatory variables. [Results] In factor analysis for each item, presence of impaired consciousness, presence of motor paralysis and FIM score were found to be outcome related, and it was revealed that those having high FIM scores without impaired consciousness or motor paralysis were discharged to home. After adjusting for age and gender in multiple regression analysis, only the FIM score was related to the outcome. [Conclusion] FIM subscale item analysis, together with family situation and housing condition are issues for future analysis directed at revealing the mechanisms determining discharge outcome as well as prognosis.

Key words: stroke, discharge to home, FIM

要旨：〔目的〕急性期脳卒中リハビリテーション患者の退院転帰の関連因子を抽出することを目的とした。〔対象〕 脳卒中の治療を目的に入退院し, 急性期のリハビリテーションを実施した患者 135 名を対象とした。〔方法〕退院転 帰（自宅退院, 転院）を目的変数とし, 年齢, 性別, リハビリテーション開始までの日数, 在院日数, 意識障害の 有無, 運動麻痺の有無, 開始時FIM（Functional Independence Measure）を説明変数とした関連要因分析を行った。 〔結果〕各項目との要因分析では, 意識障害の有無, 運動麻痺の有無, FIM 点数との関連が認められ, 意識障害が ない者, 運動麻痺がない者, FIMが高值な者が自宅退院していることが明らかになった。多重ロジスティック回帰 分析では年齢, 性別を調節後, FIM 点数との関連が認められた。〔結語〕今後はFIM下位項目別の分析, 家族状況, 家屋状況とも合わせて分析し，予後予測および退院転帰決定のメカニズムを明らかにすることが課題である。 キーワード：脳卒中，自宅退院，FIM

1) 筑波大学大学院 総合人間科学研究科 : 茨城県つくば市天王台1-1-1（テ305-8575）TEL 029-853-3436

2) 近畿大学 医学部附属病院リハビリテーション部

受付日 2010年7月1日 受理日 2010年8月23日 


\section{I. はじめに}

脳卒中は, 発症後に意識障害, 認知機能低下, 運動 麻痺，失語などの症状が起こるため，急性期病院にお いては発症後早期からのリハビリテーション開始が必 要である1)。急性期リハビリテーションの目的は廃用症 候群の予防および早期の日常生活動作の向上である ${ }^{2,3)}$ 。 急性期病院では発症後早期から十分なリスク管理のも とに早期座位・立位, 装具を用いた早期歩行訓練, 摂 食・䐵下訓練, セルフケア訓練などの積極的なリハビ リテーションを実施している。急性期病院ではリハビ リテーション開始早期に, 自宅退院が可能か, リハビ リテーション継続のための転院が必要かについて決定 する必要がある。早期の退院転帰の決定の必要性は認 識されているが，多くの課題がある。筆者らは，これ までの研究で急性期脳卒中リハビリテーション患者の 回復や退院転帰について検証している ${ }^{4,5)}$ 。しかしなが らこれまでの研究では FIM 合計得点のみでの検証であ り，意識障害や，運動麻痺など他の項目との関連につ いては検証していない。急性期の身体機能の回復は障 害部位や, 経過により大きな差があり, 退院転帰の決 定には, FIM以外の他の項目にも留意した複合的な分析 が必要である。

本研究においては，急性期脳卒中リハビリテーショ ン患者の自宅退院の関連因子につき運動麻痺, 意識障 害の有無やFIM などの複合的な要因を検討することを 目的とする。

\section{II. 対象と方法}

\section{1. 対象}

2008 年 4 月から 2010 年 2 月までにA急性期病院脳神経 外科に脳卒中（脳出血, 脳梗塞, くも膜下出血）の治 療を目的に入退院した患者 135 名を対象とした。対象者 の特性を表 1 に示す。退院転帰の内訳は自宅退院 43 名 $(31.9 \%)$ ，転院92名 $(68.1 \%)$ であった。

2. 方法

調査項目は, 年齢, 性別, リハビリテーション開始 までの日数, 在院日数, 意識障害の有無, 運動麻痺の 有無, リハビリテーション開始時と終了時のFunctional Independence Measure（以下FIM）とした。意識障害およ び運動麻痺の有無はリハビリテーション開始時に測定 した。意識障害の有無はJapan coma scale（以下JCS）を 用い, 1 以上を意識障害ありとした。運動麻痺の有無は
表1 対象者の特性

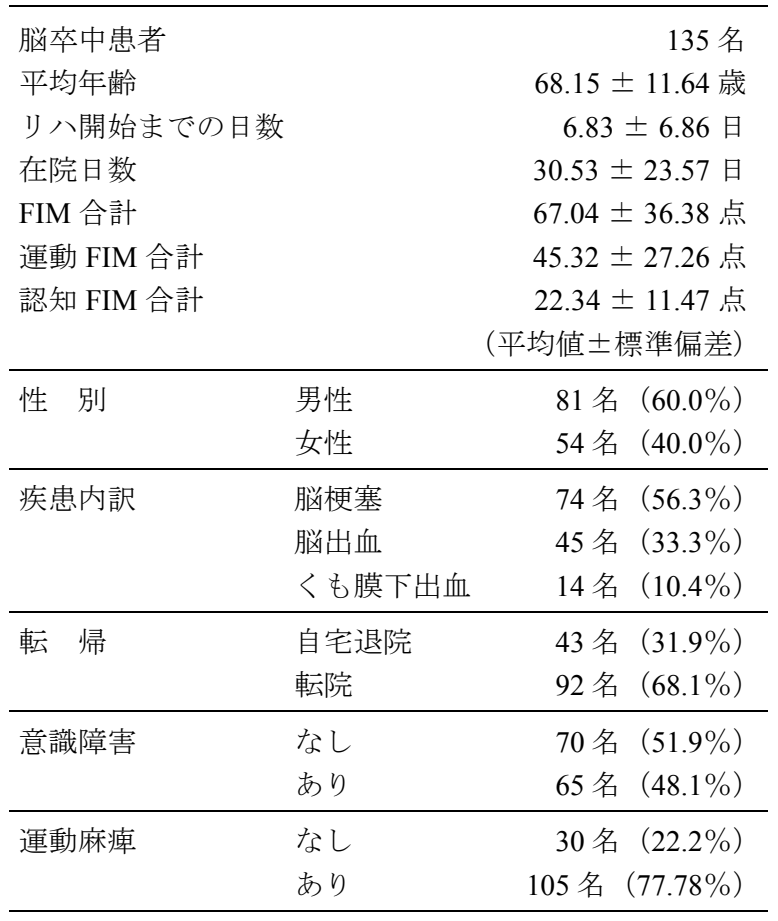

Brunntrome stage でV以下を運動麻痺ありとした。FIM ${ }^{6)}$ は日常生活動作能力の指標で, 運動項目 13 項目, 認知 項目 5 項目の計 18 項目からなる（最低 18 点，最高 126 点)。FIMは運動項目, 認知項目別の合計得点について も算出した。

解析は，退院転帰（自宅退院，転院）を目的変数と し, 年齢, 性別, リハビリテーション開始までの日数, 在院日数, 意識障害の有無, 運動麻痺の有無, 開始時 FIM を説明変数とした関連要因分析を行った。平均值 の比較は分散分析, 度数分布の比較は $\chi^{2}$ 検定を行っ た。多変量解析として，性別，年齢を調整因子とした ロジスティック回帰分析を実施した。FIM，年齢は連 続変数として投入し，性別は男を 1 ，女を 0 ，意識障害 はありを 1 , なしを 0 , 運動麻痺はありを 0 , なしを 1 と ダミー変数を設定して投入した。欠損值は分析ごとに 除外した。有意水準は $5 \%$ 未満とし, 統計処理ソフトは PC-SASを用いた。

倫理面への配慮は下記の手順で行った。評価内容は 診療録より転記した。その際，個人が特定できる情報 は削除し，個人の同定は全く不可能としている。また， 転記したデータは施錠のできるところに保管し，情報 の分析に使用されるコンピュータを含め十分に注意を 払った。 


\section{III. 結 果}

分散分析の結果を表 2 に示す。FIM 合計, 運動FIM 合 計, 認知 FIM 合計, 在院日数について有意な差が認め られ, 自宅退院の場合に FIM 得点が有意に高く, 在院 日数が有意に短いことが明らかになった。 $\chi^{2}$ 検定の結 果を表 3 に示す。意識障害, 運動麻痺について有意な差 が認められ, 意識障害がない者, 運動麻痺がない者に 有意に自宅退院の割合が高いことが明らかになった。

自宅退院に対するオッズ比を表 4 に示す。年齢，性 別, 意識レベルを調整因子とした多重ロジスティック 回帰分析において, FIM 合計（オッズ比 1.061），運動 FIM 合計（オッズ比 1.066）, 認知 FIM 合計（オッズ比 1.202）との有意な関連が認められた。

\section{IV. 考 察}

脳卒中の治療は日進月歩で変化を遂げている1)。脳 卒中の治療において, 早期からの積極的なリハビリテー ション開始は必須であり, 様々な取り組みが報告され ている ${ }^{7,8)}$ 。急性期病院のリハビリテーション開始は全 身管理と同時に平行して実施されている。

近年在院日数の短期化に伴い, スムーズな地域連携 を目的とし脳卒中を対象とした地域連携パスが作成さ れ，試験的な運用が開始されている7,8)。これに伴い急 性期病院のリハビリテーション実施においては開始初 期に退院転帰を予測し，リハビリテーションプログラ ムを作成することが必要となる。本研究では, 意識レ ベルや運動麻痺などの複合的な要因も加味して退院転 帰の関連因子を検討したという点，FIM の得点との関 連性において, 運動FIM だけでなく, 認知FIMにも注 目して分析したという点で貴重なデータが得られたと いえる。

本研究結果では, 各要因分析において, FIM 得点が 高いことと自宅退院の可否との関連性が示された。ま た, 年齢, 性別, 意識レベルを調整因子とした多重口 ジスティック回帰分析においても同様の傾向が示され た。筆者らは, FIM 得点と退院転帰との関連について 明らかにしたが, 過去の分析においては下位項目に関 する分析は実施していない。本研究ではFIM 得点を合 計点のみならず, 運動 FIM, 認知 FIM 別に分析してお り, 両 FIM 得点ともに関連が示されている。このこと から, 自宅退院の条件として, 起居動作などの運動的 側面のように身体的な介護だけでなく, 理解力などの 認知的な側面の重要性が示された。介護保険の導入か
表2 退院転帰の関連要因（分散分析）

平均值 標準偏差 有意性

\begin{tabular}{llrrr}
\hline 年齢 & 自宅退院 & 68.09 & 8.73 & \\
& 転院 & 68.17 & 12.82 & \\
リ八開始までの日数 & 自宅退院 & 6.58 & 7.05 & \\
& 転院 & 6.95 & 6.80 & \\
FIM 合計 & 自宅退院 & 100.72 & 21.96 & $* *$ \\
& 転院 & 51.29 & 30.65 & \\
運動 FIM 合計 & 自宅退院 & 69.74 & 20.11 & $* *$ \\
& 転院 & 33.90 & 22.22 & \\
認知 FIM 合計 & 自宅退院 & 32.28 & 5.85 & $* *$ \\
& 転院 & 17.70 & 10.47 & \\
在院日数 & 自宅退院 & 21.47 & 11.29 & $* *$ \\
& 転院 & 34.76 & 26.50 & \\
\hline
\end{tabular}

$* *: \mathrm{p}<0.01, *: \mathrm{p}<0.05$ （分散分析）

表3 退院転帰の関連要因

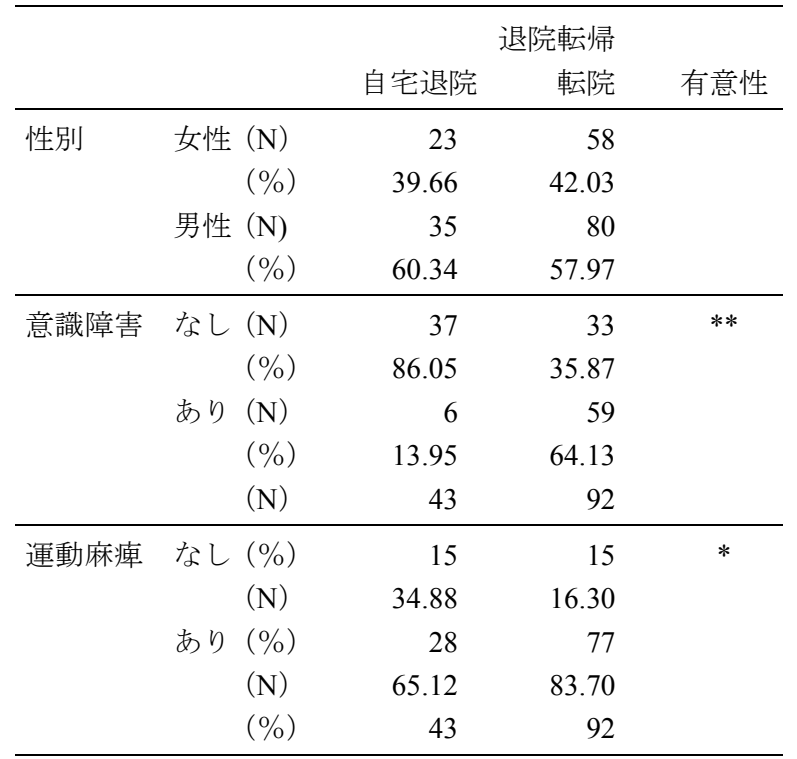

**: $\mathrm{p}<0.01, *: \mathrm{p}<0.05\left(\chi^{2}\right.$ 検定 $)$

ら 10 年以上が経過し, 社会資源を用いて自宅での生活 を獲得することの成果は多く報告されている ${ }^{10)}$ 。介護 サービスの内容は身体介護に関するものが多く占める。 訪問リハビリテーションの実施においても起居動作の 獲得のための報告が多く, 認知機能へのアプローチ実 施による成果の報告は少ない11,12)。自宅での介護, お よび機能改善のためのサービス提供においては, 身体 機能, 認知機能両面へのアプローチの必要性が示唆さ れる。 
表4 自宅退院に対するオッズ比

\begin{tabular}{|c|c|c|c|c|c|c|c|c|c|}
\hline & \multicolumn{3}{|c|}{ FIM 合計 } & \multicolumn{3}{|c|}{ 運動 FIM 合計 } & \multicolumn{3}{|c|}{ 認知 FIM 合計 } \\
\hline & オッズ比 & $\begin{array}{c}95 \% \text { 信頼 } \\
\text { 区間 }\end{array}$ & 有意性 & オッズ比 & $\begin{array}{c}95 \% \text { 信頼 } \\
\text { 区間 }\end{array}$ & 有意性 & オッズ比 & $\begin{array}{c}\text { 95\%信頼 } \\
\text { 区間 }\end{array}$ & 有意性 \\
\hline FIM(連続量で投入) & 1.061 & 1.035 & $1.087 * *$ & 1.066 & 1.037 & $1.095^{* *}$ & 1.202 & 1.102 & $1.311^{* *}$ \\
\hline 年齢 (連続量で投入) & 0.967 & 0.92 & 1.016 & 0.964 & 0.918 & 1.013 & 0.983 & 0.941 & 1.028 \\
\hline 性別(男 1 女 0) & 0.905 & 0.321 & 2.555 & 0.881 & 0.322 & 2.412 & 0.821 & 0.302 & 2.23 \\
\hline 意識障害(あり 1 なし 0) & 0.477 & 0.124 & 1.834 & 0.282 & 0.08 & $0.997 *$ & 0.639 & 0.157 & 2.607 \\
\hline 運動麻痺 (あり 1 なし 0 ) & 0.333 & 0.103 & 1.079 & 0.322 & 0.104 & 1.001 & 0.351 & 0.111 & 1.104 \\
\hline $\mathrm{H}-\mathrm{L}$ test & & 0.0728 & & & 0.6727 & & & 0.3293 & \\
\hline
\end{tabular}

**: $<<0.01, *: p<0.05$ （ロジスティック回帰分析）

また, 意識障害, 運動麻疩の有無と自宅退院の可否 との関連性についても示された。急性期は水頭症など の合併症を併発する時期であり, 意識障害がある患者 が多い。意識障害がある場合は, 呼吸器合併症の予防 や, 拘縮予防などのリハビリテーションが中心となり, 積極的な機能改善のためのリハビリテーションは遅延 することが多い。このため, 機能改善に時間を要し, 直 接の自宅退院は困難となり, 転院が必要となると考え られる。紙屋らは, 意識障害患者に早期から積極的な 介入により意識レベル改善の一助となることについて 報告している ${ }^{13)}$ このことから, 意識障害の原因によっ ては介入方法を検討し, 早期に意識レベルの改善を進 めることの必要性が示された。運動麻痺については, 原 ${ }^{14,15)}$ らは, 脳卒中発症後の運動麻痺の変化について 経時的に評価し, 初期の運動麻瘴が重度であれば, 回 復に時間を要することを明らかにしている。本研究結 果においても, 運動麻痺があることが急性期病院から の直接の自宅退院が困難であることを示している。本 研究においては運動麻痺の程度別の退院転帰について は分析しておらず，今後再分析が必要である。

本研究は, 急性期リハビリテーション実施患者の自 宅退院の可否について, 関連要因分析を行い, 意識レ ベル, 運動麻痺, 開始時 FIM 得点との関連性を明らか にした。今後はFIM 下位項目別の分析, 家族状況, 家 屋状況とも合わせて分析し，予後予測および退院転帰 決定のメカニズムを明らかにすることが課題である。

\section{引用文献}

1) 豊田章宏 : Strokeunit と急性期リハビリテーション. 脳と循
環, 2007, 12: 35-38.

2) 篠原幸人 : 脳卒中ガイドラインのインパクトと今後の課題. 総合リハビリテーション, 2005, 33: 1095-1100.

3) 篠原幸人, 吉本高志, 福内靖男・他 : 脳卒中治療ガイドライ ン2004. 協和企画, 東京, 2004.

4) 澤田優子, 鈴木雄介, 丸尾優子・他 : 急性期脳卒中リハビリ テーション患者の退院転帰の関連因子. 理学療法科学, 2009, 24(5): 659-663.

5) 鈴木雄介, 澤田優子, 福田寛二 : 当院急性期脳神経疾患少八 ビリテーションにおける疾患別特性. 大阪作業療法ジャーナ ル, 2009, 23(1): 23-27.

6) 辻 哲也 : 脳卒中医療連携におけるFIMの活用回復期から維 持期. 治療, 2008, 90: 900-907.

7) 西川順治, 山田 深, 門馬 博・他 : Strokeunitにおける急性 期脳卒中リハビリテーション． Medical Rehabilitation, 2007, 11(85): 70-75.

8) 熊崎博司, 大塚 功, 鵜飼正二・他 : 脳卒中急性期からの歩 行獲得・下肢機能改善のプログラム・下肢装具処方. Medical Rehabilitation, 2007, 11(85): 81-89.

9) 徳永 誠, 時里 香, 渡辺 進 - 他 : 3 種類の在院日数を設 定した脳卒中連携クリティカルパス. 治療, 2007, 89: 189-195.

10) 日下隆一, 原田和宏, 金谷さとみ・他: 介護保険領域におけ る理学療法のあり方に関する研究. 理学療法科学, 2008, 23(2): 219-224.

11) 伊藤隆夫 : 在宅リハビリテーションと理学療法. 理学療法科 学, 2002, 17(4): 215-220.

12) 杉本 諭: 訪問理学療法によりADL能力に改善を示した慢性 期脳卒中患者の1例. 理学療法科学, 2003, 18(4): 235-239.

13) 紙屋克子: 遷延性意識障害者におけるQOLの向上と生活の再 構築. EB Nursing, 2008, 9(1): 60-67.

14) 原 寛美: 脳卒中急性期リハビリテーションの現状. 救急医 学, 2008, 32(11): 1593-1598.

15) 滝沢歩武, 原 寛美: 脳卒中急性期リハビリテーションの離 床プログラム． Medical Rehabilitation，2007, 11(85): 76-80. 